\title{
Effect of Grape Seed Extract on Oxidative Damages in Gamma Irradiated Rats
}

\author{
Abdelgawad.A. Fahmi' ${ }^{1}$, M.A.El- Desouky ${ }^{1}$, Neama M. El-Fatih², Wissam.A.Mohamed ${ }^{1}$ \\ ${ }^{1}$ Chemistry Department, Faculty of Science, Cairo university and ${ }^{2}$ Radiation Biology Department, \\ National Centre for Radiation Research and Technology (NCRRT), Cairo, Egypt
}

\begin{abstract}
Back ground: Ionizing radiation is known to produce deleterious effects in the living organisms.
\end{abstract}

Aim of the work: The aim of this study is to evaluate the possible protective effect of the chemical constituents of grape seed extract on oxidative stress induced by gamma rays.

Materials \& Methods: Rats were subjected to 8 Gy fractionated doses of gamma radiation, grape seed extract $100 \mathrm{mg} / \mathrm{kg}$ body weights were daily administrated before and within radiation exposure. All parameters were investigated at $1^{\text {st }}$ and $14^{\text {th }}$ days post last radiation exposure.

Results: The results revealed that administration of grape seed extract to irradiated rats significantly ameliorates the changes induced in antioxidant system. TBARS (lipid peroxidation index) were significantly decreased when compared with their equivalent values in irradiated rats.

In conclusion, the administration of grape seed extract to irradiated rats might provide substantial protection against oxidative damages due to its free radical scavenging and antioxidant properties of its ingredients. It could be suggested that, grape seed extract may have a potential benefits to people receiving radiotherapy.

Key words: Grape seed extract, $\gamma$-Irradiation, Oxidative Stress, Mitochondria, and Antioxidant Enzymes.

\section{Introduction}

Radiation damage, is to a large extent caused by over production of reactive oxygen species(ROS) which cause disruption of membrane lipids leading to subsequent formation of peroxide radicals (Rajapakse et al.,2007). Experimental studies have demonstrated that exposures to ionizing radiation induce oxidative stress in different tissues (Saada et al., 2003; Said et al., 2004). ROS and oxidative stress may contribute to radiation-induced cytotoxicity and to metabolic and morphologic changes in animals and humans during radiotherapy, 
experimentation, or even space flight (Fang et al., 2002).

Mitochondria are the main cellular organelles that are involved in free radical production. Mitochondria consume about $90 \%$ of the cellular oxygen and are the most susceptible organelles to oxidative damage (Khansari et al., 2009). Mitochondria are a major source of ROS, which are a by-product of mitochondrial electron transfer activity (Gustafsson et al., 2008). Since mitochondria are the major site of free radical generation, they are highly enriched with antioxidants including GSH and enzymes, such as superoxide dismutase (SOD) and glutathione peroxidase (GPx), which are present on both sides of their membranes in order to minimize oxidative stress in the organelle (Cadenas and Davies,2000). The lack of equilibrium between free radical production in mitochondria and anti-oxidant defense mechanisms in this organelle may leads to leak of these harmful reactants to cytoplasm or connective tissues

\section{(Khansari et al., 2009).}

Over the past decades, researchers have become increasingly interested in polyphenolic compounds. The chief reason for this interest is recognition of their antioxidant properties and their probable role in the prevention of various degenerative-diseases associated with oxidative-stress, such as cancer and cardiovascular-diseases (Manach et al., 2005).

Grape seed extract (GSE) is a natural extract from the seeds of Vitis vinifera, rich in flavonoids, mainly flavan-3-ols and proanthocyanidins (Ferreira and Li, 2000). These flavonoids have demonstrated a marked spectrum of biological, pharmacological, therapeutic, and chemoprotective properties against oxygen free radicals and oxidative stress (Bagchi et al., 2000). Grape seed proanthocyanidin extract (GSPE) has more powerful antioxidative activity than other well-known antioxidants, including vitamin $\mathrm{C}$, vitamin $\mathrm{E}$, and gallic acid (Ariga, 2004). GSPE has various biological functions such as antibacterial, antiviral, anti-inflammatory, anti-allergic, and vasodilatory actions (Bagchi et al., 2000).

The present study was planned to elucidate the possible antioxidative and radioprotective effect of grape seed extract as a natural phytochemical compound against oxidative damage induced through extended exposure to ionizing radiation in rats. 


\section{Material and Methods}

\section{Experimental Plant:}

GSE from Vitis vinifera was obtained from the vitamin shoppe. The product is supplied as tablets of $100 \mathrm{mg}$ (standardized to $90 \%$ proanthocyanidins $90 \mathrm{mg}$ ). Tablets were dissolved in water and animals received by gavages the equivalent of $100 \mathrm{mg} / \mathrm{Kg}$ body weight/day (Said et al., 2005).

\section{Experimental animals:}

Forty eight adult male albino rats $(100-120 \mathrm{~g})$ were obtained from the animal farm of the Egyptian Holding Company for Biological Products and Vaccines (VACSERA); Cairo, Egypt. The Animals were kept in isolated cages, under standard laboratory condition including all hygienic measures with constant illumination and ventilation, temperature and humidity. Animals were maintained on a starter poultry pellets and water ad libitum. All animals received human care in compliance with institutional guidelines.

\section{Radiation process}

Irradiation processing was performed using Canadian gamma cell-40, $\left({ }^{137} \mathrm{Cs}\right)$ at the National Centre for Radiation Research and Technology (NCCRT), Cairo, Egypt. Animals were subjected to fractionated whole body $\gamma$-radiation; delivered as $2 \mathrm{~Gy}$ every other day up to total dose of $8 \mathrm{~Gy} \cdot{ }^{137} \mathrm{Cs}$ source offers a dose rate of $0.61 \mathrm{~Gy} / \mathrm{min}$ at the time of experiment.

\section{Experimental design}

The rats were randomly distributed into 4 groups $(n=12$, 6-rats/group for each time interval). Group (I): served as controls. Group (II): Animals received Grape seed extract by stomach tube in a dose of $100 \mathrm{mg} / \mathrm{kg}$ body weight for 14 successive days throughout exposure to gamma radiation. Group (III): subjected to fractionated whole body $\gamma$-radiation up to total dose of 8 Gy. Group (IV): Animals were received Grape seed extract as described in group II and subjected to gamma irradiation as described in group III.

\section{Samples collection}

Animals were fasted over night prior to sacrificing. Samples were collected at $1^{\text {st }}$ and $14^{\text {th }}$ days post irradiation Whole blood was withdrawn by means of heart puncture technique Blood samples were allowed to clot at room temperature then centrifuged at $5000 \mathrm{rpm}$ for $15 \mathrm{~min}$. Serum samples were aspirated, divided into two Eppendorff vials, and stored at $20^{\circ} \mathrm{C}$ until analysis. Part of liver tissue was dissected, weighed and homogenized in physiological saline $(9 \mathrm{~g} \mathrm{Nacl} / 1000 \mathrm{ml}$ distilled water) $(10 \% \quad \mathrm{w} / \mathrm{v}) . \quad$ The 
homogenate was centrifuged at $9000 \mathrm{x} \mathrm{g}$ for $20 \mathrm{~min}$ using cooling centrifuge (Memmert, MLW, and GDR). The pellet was discarded and the supernatant was stored at $-20^{\circ} \mathrm{C}$ until used for of biochemical analysis.

Another part of Liver was removed, and homogenized in $0.25 \mathrm{M}$ sucrose containing $1 \mathrm{mM}$ EDTA. The homogenate was centrifuged at $3000 \mathrm{~g}$ for

\section{Biochemical assays}

Lipid peroxide content was determined by quantifying the thiobarbituric acid reactive substances (TBARs) level in liver and mitochondrial liver tissue homogenates according to the method described by Yoshioka et al. (1979). Superoxide dismutase (SOD) activity was determined according to the method of kakker et al. (1984). Determination of reduced glutathione (GSH) content was performed according to Ellman (1959). Catalase (CAT)

\section{Results}

The thiobarbituric acid reactive substances (TBARs) concentrations in liver tissues of animals exposed to fractionated $\gamma$-irradiation with or without Grape seed extract treatment are presented in Table (1). There were elevations in liver (TBARs) concentration of irradiated groups as compared to control and Grape seed extract groups all
$10 \mathrm{~min}$ to remove cell debris and the nuclear fraction. The resulting supernatant was centrifuged at $10,000 \mathrm{~g}$ for $10 \mathrm{~min}$ to sediment mitochondria in the centrifuge. The mitochondrial pellets thus obtained were washed thrice with 5 $\mathrm{mM}$ potassium phosphate buffer $\mathrm{pH} 7.4$ to remove sucrose and were suspended in the same buffer (Kamat et al., 1997). activity was determined according to the method described by sinha (1972). Estimation of glutathione peroxidase (GSH-Px) activity was performed after the method of Gross et al. (1967). Tissues total protein content was assayed according to Lowry et al. (1951).

Statistical analysis was performed by using Duncan's multiple range tests using SAS "Statistical Analysis System" Institute, (1988). The results were presented as means \pm SE

over the experimental periods. The prolonged administration of Grape seed extract throughout exposure to fractionated $\gamma$ - irradiation induced a decrease in TBARs contents of liver tissue compared to irradiated animals $(P<$ $0.05)$, while a significant decrease of SOD, GSH and CAT activity in liver tissues of animals exposed to fractionated 
$\gamma$-radiation in comparison with respective control groups all over the experimental periods. Administration of Grape seed extract attained a significant increase in SOD, GSH and CAT activity $(P<0.05)$ in comparison with $\gamma$-irradiated groups at both time intervals.

The thiobarbituric acid reactive substances (TBARs) concentrations in liver mitochondrial tissues of animals exposed to fractionated $\gamma$-irradiation with or without Grape seed extract treatment are presented in Table (2). There were elevations in liver mitochondrial (TBARs) concentration of irradiated groups as compared to control and Grape seed extract groups all over the experimental periods. The prolonged administration of Grape seed extract throughout exposure to fractionated $\gamma$ irradiation induced a decrease in TBARs contents of liver mitochondrial tissue compared to irradiated animals $(P<0.05)$, while a significant decrease of SOD, GSH and GSH-Px activity in liver mitochondrial tissues of animals exposed to fractionated $\gamma$-radiation in comparison with respective to control groups all over the experimental periods. Administration of Grape seed extract attained a significant increase in SOD, GSH and GSH-Px activity $(P<0.05)$ in comparison with $\gamma$-irradiated groups at both time intervals. 
Table (1): Effect of grape seed extract on lipid peroxidation (TBARS), superoxide dismutase (SOD), reduced glutathione (GSH) content and catalase(CAT) activity in liver tissues of different animals groups subjected to fractionated $\gamma$-radiation.

Data are presented as mean $\pm \mathrm{SE}$

Similar characters denote insignificance difference between groups using Duncan Multiple Range Test for comparative Means at $(\mathrm{P}<0.05)$

\begin{tabular}{|c|c|c|c|c|c|}
\hline \multirow[t]{2}{*}{ Parameters } & \multirow{2}{*}{$\begin{array}{l}\text { Experimental } \\
\text { period(days) }\end{array}$} & \multicolumn{4}{|c|}{$\operatorname{Groups}(n=6)$} \\
\hline & & control & GSE & Irradiated & GSE+irradiated \\
\hline \multirow{2}{*}{$\begin{array}{l}\text { TBARS } \\
\text { (nmole/g } \\
\text { wet tissue) }\end{array}$} & 1 day & $\begin{array}{l}268.85 \pm 2.17 \\
\mathrm{c}\end{array}$ & $\begin{array}{l}263.58 \pm 1.95 \\
\mathrm{c}\end{array}$ & $404.70 \pm 3.93 a$ & $350.83 \pm 2.99 b$ \\
\hline & 14 day & $\begin{array}{l}260.52 \pm 1.36 \\
\text { c }\end{array}$ & $\begin{array}{l}256.18 \pm 1.11 \\
\mathrm{c}\end{array}$ & $\begin{array}{l}381.52 \pm 2.96 \\
\mathrm{a}\end{array}$ & $330.44 \pm 2.62 \mathrm{~b}$ \\
\hline \multirow{2}{*}{$\begin{array}{l}\text { SOD } \\
\text { (U/mg } \\
\text { protein) }\end{array}$} & 1 day & $2.77 \pm 0.06 b$ & $2.83 \pm 0.04 \mathrm{a}$ & $2.13 \pm 0.04 d$ & $2.35 \pm 0.04 \mathrm{c}$ \\
\hline & 14 day & $2.87 \pm 0.06 \mathrm{a}$ & $2.89 \pm 0.03 \mathrm{a}$ & $2.14 \pm 0.05 \mathrm{c}$ & $2.48 \pm 0.03 \mathrm{~b}$ \\
\hline \multirow{2}{*}{$\begin{array}{l}\text { GSH } \\
\text { (mg/g wet } \\
\text { tissue) }\end{array}$} & 1 day & $22.44 \pm 0.43 \mathrm{a}$ & $22.69 \pm 0.26 \mathrm{a}$ & $17.06 \pm 0.39 \mathrm{c}$ & $20.24 \pm 0.21 b$ \\
\hline & 14 day & $23.03 \pm 0.34 \mathrm{a}$ & $23.33 \pm 0.21 \mathrm{a}$ & $18.68 \pm 0.34 \mathrm{c}$ & $21.30 \pm 0.18 \mathrm{~b}$ \\
\hline \multirow{2}{*}{$\begin{array}{l}\text { CAT } \\
\text { (U/mg } \\
\text { protein) }\end{array}$} & 1 day & $4.37 \pm 0.11 \mathrm{a}$ & $4.42 \pm 0.10 \mathrm{a}$ & $2.85 \pm 0.05 \mathrm{c}$ & $3.62 \pm 0.03 b$ \\
\hline & 14 day & $4.29 \pm 0.08 \mathrm{a}$ & $4.32 \pm 0.03 \mathrm{a}$ & $2.97 \pm 0.03 \mathrm{c}$ & $3.64 \pm 0.10 \mathrm{~b}$ \\
\hline
\end{tabular}


Table (2): Effect of grape seed extract on lipid peroxidation (TBARS), superoxide dismutase (SOD), reduced glutathione (GSH) and glutathione peroxidase(GSH-Px) activity in mitochondrial liver tissues of different animals groups subjected to fractionated $\gamma$ - radiation.

Data are presented as mean \pm SE

Similar characters denote insignificance difference between groups using Duncan Multiple Range Test for comparative Means at $(\mathrm{P}<0.05)$.

\begin{tabular}{|l|l|l|l|l|l|}
\hline \multirow{2}{*}{ Parameters } & \multirow{2}{*}{$\begin{array}{l}\text { Experimental } \\
\text { period(days) }\end{array}$} & \multicolumn{4}{|c|}{ Groups(n=6) } \\
\cline { 3 - 6 } & $\mathbf{1}$ day & $97.97 \pm 0.66 \mathrm{c}$ & $97.85 \pm 0.78 \mathrm{c}$ & $147.30 \pm 1.40 \mathrm{a}$ & $124.42 \pm 1.30 \mathrm{~b}$ \\
\hline $\begin{array}{l}\text { TBARS } \\
\text { tissue) }\end{array}$ & $\mathbf{1 4}$ day & $93.18 \pm 0.70 \mathrm{c}$ & $93.10 \pm 0.81 \mathrm{c}$ & $131.37 \pm 1.75 \mathrm{a}$ & $112.93 \pm 1.24 \mathrm{~b}$ \\
\cline { 2 - 6 } & $\mathbf{1}$ day & $2.36 \pm 0.05 \mathrm{a}$ & $2.44 \pm 0.06 \mathrm{a}$ & $1.20 \pm 0.08 \mathrm{c}$ & $1.71 \pm 0.08 \mathrm{~b}$ \\
\hline $\begin{array}{l}\text { SOD } \\
\text { (U/mg } \\
\text { protein) }\end{array}$ & $\mathbf{1 4}$ day & $2.40 \pm 0.01 \mathrm{a}$ & $2.41 \pm 0.01 \mathrm{a}$ & $1.33 \pm 0.11 \mathrm{c}$ & $2.06 \pm 0.07 \mathrm{~b}$ \\
\hline $\begin{array}{l}\text { GSH } \\
\text { (mg/g } \\
\text { wet tissue) }\end{array}$ & $\mathbf{1}$ day & $17.01 \pm 0.19 \mathrm{a}$ & $17.33 \pm 0.26 \mathrm{a}$ & $13.30 \pm 0.11 \mathrm{c}$ & $15.09 \pm 0.06 \mathrm{~b}$ \\
\cline { 2 - 6 } & $\mathbf{1 4}$ day & $19.15 \pm 0.20 \mathrm{a}$ & $19.21 \pm 0.30 \mathrm{a}$ & $14.70 \pm 0.34 \mathrm{c}$ & $17.18 \pm 0.12 \mathrm{~b}$ \\
\hline $\begin{array}{l}\text { GSH-Px } \\
\text { (U/mg } \\
\text { protein) }\end{array}$ & $\mathbf{1}$ day & $0.51 \pm 0.01 \mathrm{a}$ & $0.52 \pm 0.02 \mathrm{a}$ & $0.32 \pm 0.01 \mathrm{c}$ & $0.37 \pm 0.02 \mathrm{~b}$ \\
\cline { 2 - 6 } & $\mathbf{1 4}$ day & $0.53 \pm 0.00 \mathrm{a}$ & $0.53 \pm 0.00 \mathrm{a}$ & $0.38 \pm 0.01 \mathrm{c}$ & $0.46 \pm 0.00 \mathrm{~b}$ \\
\hline
\end{tabular}

\section{Discussion}

The deleterious effects of ionizing radiation in biological systems are mainly mediated through the generation of reactive oxygen species (ROS) in cells as a result of water radiolysis (Kamat et al., 2000). In this context, the potential of antioxidants to reduce the cellular damage and cytotoxic effects induced by ionizing radiation has been extensively studied in animal for the last few decades (Okunieff et al., 2008).

Numerous studies have suggested positive associations between the consumption of phenolic-rich foods or 
beverages and the prevention of disease (Scalbert and Williamson, 2000). Grape seed extract (GSE), a well-known dietary supplement, contains important vitamins, minerals, and polyphenols including flavonoids, proanthocyanidins and procyanidins (Weber et al., 2007). Grape seed proanthocyanidin extract (GSPE) has more powerful antioxidative activity than other well-known antioxidants, including vitamin $\mathrm{C}$, vitamin $\mathrm{E}$, and gallic acid (Ariga et al., 2004). Proanthocyanidin from grape seeds have been reported to show various beneficial properties including hepatoprotective effects as well as modulatory role on agerelated oxidative DNA damage (Balu $\boldsymbol{e t}$ al., 2006).

The present study attains that enhancement of TBARS concentration; concomitant with depletion of antioxidant parameters (SOD, GSH, CAT and GSH$\mathrm{Px}$ ) in liver and liver mitochondrial tissues is a characteristic observation in $\gamma$ irradiated animals.

Lipid peroxidation, a process induced by free radicals leads to oxidative deterioration of polyunsaturated lipids (Català, 2009). Under normal physiological conditions, only low levels of lipid peroxides occur in body tissues. The excessive generation of free radicals leads to peroxidative changes that ultimately result in enhanced lipid peroxidation (Joshi et al., 2007). The increase in TBARS level might result from the interaction of the highly reactive $\mathrm{OH}^{\cdot}$ produced in the cell as the result of irradiation on polyunsaturated fatty acid in the phospholipids portion of cellular membranes which initiating lipid peroxidation cell reaction (Spitz et al., 2004). The present result are in line with that obtained by (Cai et al., 2010) who suggested that Ionizing radiation resulted in a significant increase in the content of MDA, a biomarker of lipid peroxide in rats liver mitochondria causing radiationinduced mitochondrial dysfunction and oxidative damage.

GSE treatment has significantly minimized the formation of lipid peroxidation products obvious by a lower level of TBARS in liver and liver mitochondrial tissues when compared to their corresponding values in irradiated rats. The results are consistent with Hüseyin et al. (2007) who reported that GSE enhanced the antioxidant status and decreased the incidence of free radicalinduced lipid peroxidation when administered to rats before whole-body irradiation. Furthermore, experimental studies have demonstrated that GSE protects against oxidative stress by doubling the intracellular synthesis of 
anti-oxidative enzymes (Puiggros et al., 2005). Also (Lu et al., 2004) stated that treatment with procyanidins from grape seeds in hepatic mitochondrial tissues markedly decreased The MDA levels which agree with our results.

SOD catalyses the dismutation of the highly reactive $\mathrm{O}_{2}$ to oxygen and to the less reactive species, $\mathrm{H}_{2} \mathrm{O}_{2}$ (Shijun et al., 2000 and Matsumoto and Fridovich, 2001). Thus the decrease in the activity of SOD observed in the present study could be due to feed back inhibition or oxidative inactivation of SOD due to excess ROS generation. Also (Kamat $\boldsymbol{e t}$ al., 2000) stated that the inactivation of superoxide dismutase (SOD), one of the antioxidant enzymes together with protein thiols, the efficient scavengers of ROS involved in the maintenance of the integrity of the membranes confirmed the oxidative damage following exposure to $\gamma$-radiation in rat liver mitochondria.

The present study indicated that GSE pre-treatment increase SOD activities in liver and liver mitochondrial tissues. This may be due to that the chemical properties of proanthocyanidins in terms of the availability of the phenolic hydrogens as hydrogen donating radical scavengers and singlet oxygen quenchers predicts their antioxidant activity (Bagchi et al., 2000).
Glutathione is the most abundant nonprotein sulfhydryl containing compound and constitutes the largest component of the endogenous thiol buffer (Holmgren et al., 2005).

The depletion of GSH recorded in irradiated animals in liver and liver mitochondrial tissues are in agreement with Kamat et al. (2000), which may be due to their utilization in large amount to combat the radiation induced, Freeradical damage, as glutathione is a major non-enzymatic antioxidant, where reduced glutathione (GSH) participate in the cellular system of defense against oxidative damage directly as a free radical scavenger or indirectly by repairing initial damage to macromolecules and could maintain protein and non-protein $\mathrm{SH}$ group in reduced form (Ross, 1988; Scibior et al., 2008). The results obtained by this study are in line with (Rajendra et al., 2005) who stated that the decrease in the activities of GSH in hepatic tissues of mitochondria may be due to their utilization by the enhanced production of ROS.

The present study indicated that GSE pre-treatment increase GSH, activities in liver and liver mitochondrial tissues; a possible mechanism explains the results that GSE contains mainly flavonoids. Numerous flavonoids have been shown to 
alleviate the oxidative stress by increasing the endogenous antioxidant status, protecting cells against free-radical damage by increasing resistance to oxidative stress (Zwart et al., 1999; Perez et al., 2002).

CAT is one of the most efficient enzymes known. CAT protects cells from hydrogen peroxide generated within them. Even though CAT is not essential for some cell types under normal conditions, it plays an important role in the acquisition of tolerance to oxidative stress in the adaptive response of cells (Hunt et al., 1998; Oral et al., 2000). The recorded depletion of enzymatic activity of CAT may be due to the increased utilization of this antioxidant to counteract lipid peroxidation production, however CAT removing $\mathrm{H} 2 \mathrm{O} 2$ which occurred (Kalpana and Menon, 2004).

The present study indicated that GSE pre-treatment increase CAT activities in liver. The results are in line with that obtained by (Cetin et al., 2008) who suggested that GSE treatment considerably increased the formation of antioxidants products in hepatocytes which represented by increase in SOD, CAT activities and this effect may be due to the phenolic composition of GSE and its antioxidant activity.
GSH-Px has a well-established role in protecting cells against oxidative injury. GSH-Px utilizes GSH as a substrate to catalyse the reduction of organic hydroperoxides and $\mathrm{H}_{2} \mathrm{O}_{2}$ (Ray and Husain, 2002). Li et al. ( 2007) found that exposure of rat liver mitochondria to $\gamma$-irradiation lead to decrease in SOD and GSH-Px activity which may be due to that irradiation-induced ROS markedly alters the physical, chemical and immunologic properties of endogenetic antioxidant enzymes (SOD, CAT, and GSHPx), which further increase oxidative damage in cells. The cytotoxic effect of free radicals is deleterious to mammalian cells.

The present study indicated that GSE pre-treatment increase GSH-Px activities in liver mitochondrial tissues (Alía et al., 2003) reported that glutathione peroxidase activity increased after consumption of grape seeds and grape skins. These results were supposedly caused by polyphenols in the grape seeds. It has been generally recognized that polyphenols have numerous important beneficial effects on oxidative stress, including inhibition of inflammation, inhibition of LDL oxidation, and protection of cells and tissues from oxidative damage (Quettier-Deleu et al., 2003 and Schreckinger et al., 2010). 
In conclusion, the present results suggest that grape seed extract constituents controlled the excess production of free radicals produced by gamma irradiation and has a protective effect against oxidative stress by decreasing liver and liver mitochondrial lipid peroxide concentrations and increasing the antioxidant system. It would protect the liver and liver mitochondrial tissues from oxidative damage; preserve the integrity of tissue functions.

\section{References}

Alía M, Horcajo C, Bravo $L$ and Goya $L$ (2003): Effect of grape antioxidant dietary fiber on the total antioxidant capacity and the activity of liver antioxidant enzymes in rats. Nutr Res, 23:1251-67.

Ariga T (2004): The antioxidative function, preventive action on disease and utilization of proanthocyanidins. Biofactors, 21 (1-4):197201.

Bagchi D, Bagchi M, Stohs SJ, Das DK, Ray SD,Kuszynski CA. et al.(2000): Free radicals and grape seed proanthocyanidin extract: importance in human health and disease prevention. Toxicology, 148:187-97.

\section{Balu M, Sangeetha P, Murali Gand} Panneerselvam C (2006): Modulatory role of grape seed extract on age-related oxidative DNA damage in central nervous system of rats. Brain Res Bull, 68(6):469-73.

\section{Cadenas Eand Davies KJA (2000):} Mitochondrial free radical generation, oxidative stress, and aging, Free Rad. Biol. Med., 29: 222-230.

Cai X, Hao J, Zhang X, Yu B, Ren J, Luo C, Li Q, Huang Q, Shi X, Li W and Liu J (2010): The polyhydroxylated fullerene derivative $\mathrm{C} 60(\mathrm{OH}) 24$ protects mice from ionizing-radiation-induced immune and mitochondrial dysfunction. Toxicology and Applied Pharmacology, 243: 27-34

Catalá A (2009): Lipid peroxidation of membrane phospholipids generates hydroxylalkenals and oxidized phospholipids active in physiological and / or pathological conditions. Chem.Phys.Lipids, 157(10):1-11.

Cetin A, Kaynar L, Kocyigit I, Hacioglu S K, Saraymen R, Ozturk A, Orhan O and Sagdic $O$ (2008): The effect of grape seed extract on radiation-induced oxidative stress in the rat liver. Turk J Gastroenterol; 19 (2): 92-98.

Ellman GL (1959): Tissue sulfhydryl groups. Arch. Biochem. Biophys ., 82: 70-77.

Fang Y, Yang S and Wu G (2002): Free radicals, antioxidants, and nutrition. Nutrition, 18: 872-879.

Ferreira D and Li XC (2000): Oligomeric Proanthocyanidins: Naturally Occurring Oheterocycles. Nat Prod Rep, 17: 193-212.

Gross R T, Bracci R, Rudolph N, Schroeder E and Kochen J A (1967): Hydrogen peroxide toxicity and detoxification in the erythrocytes of newborn infants. Blood, 29: 481-493.

Gustafsson A B, Gottlieb R A (2008): Heart mitochondria: Gates of life and death. Cardiovasc. Res, 77: 334-343. 
Hologram A, Johansson C, Berndt C, Lonn M E, Hudemann C and Lillig C H (2005):

Thiol redox control via thioredoxin and glutaredoxin systems. Biochem. Soc. Trans., 33: 1375-1377.

Hunt C, Sim J E, Sullivan $\mathbf{S}$ J, Featherstone T, Golden W, Kapp-Herr C V,Hock R A, Gomez R A, Parsian J A and Spitz D R (1998): Genomic instability and catalase gene amplification induced by chronic exposure to oxidative stress. Cancer Res, 58: 3986-3992.

Hüseyin E, Mustafa $C$, Turan $K$ and Perihan U (2007): Effect of grape seed extract on lipid peroxidation, antioxidant activity and peripheral blood lymphocytes in rats exposed to x-radiation. Phytotherapy Research, 21 (11):1029- 1035.

Joshi R, Kamet J P and Mukherjee T (2007):Free radical scavenging reactions and antioxidant activity of cmbelin: Biochemical and pluse radiolytic studies. Chem. Biol.Interact., 167(2):125.

Kakkar P, Das B and Visvanathan P N (1984): A modified spectrophotometric assay of superoxide dismutase. Indian J. Biochem. Biophys, 21: 130-132.

Kalpana C and Menon V P (2004): Modulatory effects of Curumin on lipidperoxidation and antioxidant status during nicotine induced toxicity.Pol.J. Pharmacol , 56:581.

Kamat $\mathbf{J}$ P, Devasagayam $\mathbf{T} \mathbf{P}$, Priyadarsini K I and Mohan H (2000): Reactive oxygen species mediated membrane damage induced by fullerene derivatives and its possible biological implications. Toxicology, 155: 55-61.

Kamat J P, Sarma H D, Devasagayam T P A, Nesaretnam $K$ and Basiron $Y$ (1997): Tocotrienols from palm oil as effective inhibitors of protein oxidation and lipid peroxidation in rat liver microsomes. Molecular and Cellular Biochemistry, 170: 131-138.

Khansari M, Shakiba Y and Mahmoudi M (2009): Chronic Inflammation and Oxidative Stress as a Major Cause of Age- Related Diseases and Cancer. Recent Patents on Inflammation \& Allergy Drug Discovery, 3: 73-80.

Li X L, Zhou A G and Li X M (2007): Inhibition of Lycium barbarum polysaccharides and Ganoderma lucidum polysaccharides against oxidative injury induced by $\gamma$-irradiation in rat liver mitochondria. Carbohydrate Polymers, 69: 172-178.

Lowry O H, Rosenborough N J, Farr A L and Randal $R \quad J$ (1951): Protein measurement with folin phenol reagent. $J$ .Biol.Chem, 193: 265-275.

\section{LU Y, ZHAO Zai W Z, CHANG CHEN W} $X$ and LI L (2004): Procyanidins from grape seeds protect against phorbol esterinduced oxidative cellular and genotoxic damage , Acta Pharmacol Sin , 25 (8): 10831089.

$\begin{array}{llll}\text { Manach } & \text { C, Scalbert A, Morand C, } \\ \text { Remesy } & \text { C and Jimenez L } & \text { (2005) }\end{array}$ Bioavailability and bioefficacy of polyphenols 
in humans. Am. J. Clin. Nutr: 81(1): 230S$242 \mathrm{~S}$

Matsumoto A O and Fridovich I (2001): Subcellular distribution of superoxide dismutases (SOD) in rat liver: $\mathrm{Cu}, \mathrm{Zn}-\mathrm{SOD}$ in mitochondria. J. BioI. Chem, 276: 383-388.

Okunieff P,Swarts S, Keng P, Sun W, Wang W, Kim J, Yang S, Zhang H, Liu C, Williams J P, Huser A K and Zhang L (2008) Antioxidants reduce consequences of radiation exposure. Adv. Exp. Med. Biol, 614:165-178.

Oral B H, George J T A, and Haskard O D (2000): Prevention of hydrogen peroxide- and cisplatin-induced apoptosis by intracellular catalase overexpression. Turk. $J$. Biol,. 24: 685-696.

Perez D, Strobel P, Foncea R.; et al. (2002):Wine, diet, antioxidant defences and oxidative damage. Ann NY Acad Sci, 957: 136-45.

Puiggros F,Llopiz N, Ardevol A, Blade C,Arola L and Salvado M J (2005): Grape seed procyanidins prevent oxidative injury by modulating the expression of antioxidant enzyme systems. J Agric Food Chem, 53(15):6080-6.

Quettier-Deleu C, Voiselle G, Fruchart J C, Duriez P, Teissier E, Bailleul F,Vasseur J and Trotin F (2003): Hawthorn extracts inhibit LDL oxidation. Pharmazie, 58:577-81.

Rajapakse N, Kim M M, Mendis E and Kim S K (2007): Inhibition of free radical mediated oxidation of cellular biomolecules by carboxylated chitoologosaccharides. Bioorg. Med. Chem, 15(2):997.
Rajendra- Prasad N, Menon V P, Vasudev $V$ and Pugalendi KV (2005): Radioprotective effect of sesamol on $\gamma$ radiation induced DNA damage, lipid peroxidation and antioxidants levels in cultured human lymphocytes. Toxicology, 209:225-35.

Ray G and Husain S A (2002): Oxidants, antioxidants and carcinogenesis. Ind. J. Exp. Biol, 42: 1213-1232.

Ross D (1988): Glutathione, free radicals and chemotherapeutic agents. Pharmacol. Ther, 37: 231-249.

Saada H N, Said U Z and Mahdy A M (2003): Effectiveness of Aloe vera on the antioxidant status of different tissues in irradiated rats. Pharmazie ,58: 929-931.

Said U Z (2004): Neuroprotective properties of rutin in radiationinduced biochemical disorders in brain of rats. Arab $J$ of Nuclear Sci and Appl, 37 (3): 223-231.

Scalbert A and Williamson G (2000) Dietary intake and bioavailability of polyphenols. J. Nutr, 130(8S):2073-2085.

Schreckinger M E, Wang J, Yousef G,Lila $M A$ and de -Mejia E G (2010): Antioxidant capacity and in vitro inhibition of adipogenesis and inflammation by phenolic extracts of Vaccinium floribundum and Aristotelia chilensis. J Agric Food Chem ,58:8966-76.

Scibior D, Skrzycki M, Podsiad $M$ and Czeczot H (2008): Glutathione level and glutathione-dependent enzyme activities in blood serum of patients with gastrointestinal tract tumors. Clin. Biochem, 41: 852-858. 


\section{Shijun L I, Tao Y J I,Qin Y, Terry D O}

and Larry W O (2000): The role of cellular glutathione peroxidase redox regulation in the suppression of tumor cell growth by manganese superoxide dismutase. Cancer Res, 60: 3927-3939.

Sinha K A . (1972): Colorimetric assay of catalase. Anal. Biochem, 47: 389-394.

Spitz D R, Azzam E L, Li J J and Gius D (2004):Metabolic Oxidation /Reduction Reaction and cellular responses to Ionizing Radiation :A unifing Concept in Stress Response Biology Cancer and Metastasis Review ,23:311- 322.

Weber H A, Hodges A E, Guthrie J R, O'Brien B M, Robaugh D, Clark A P,
Harris R K , Algaier J W and Smith C S ( 2007): Comparison of proanthocyanidins in commercial antioxidants: grape seed and pine bark extracts. J. Agric. Food Chem, 55: 148156.

Yoshioka T, Kawada K, Shimada T and Mori M (1979): lipid peroxidation in maternal and cord blood and protective mechanism against activated-oxygen toxicity in the blood. Am. J. Obstet. Gynecol, 135: 372-376.

\section{Zwart L,Meerman J H and Commandeur}

J N M.; et al. (1999): Biomarkers of free radical damage. Applications in experimental animals and in humans. Free Radic Biol Med, 26: 202-26. 
الملخص العربي

تأثير مستخلص بذور العنب علي أضرار التأكسد في الجرذان المعرضة لأشعة جامـا

عبد الجو اد علي فهمي1, محمد علي الاسوقي,نعمة محمد الفاتح,وسام عبد الحميد محمد1

1كلية العلوم - قسم الكيمياء- جامعة القاهرة, 2المركز القومي لبحوث وتكنولوجيا الأشعاع- هيئة الطاقة الذرية

الهدف من هذه الدراسة هو تقييم التأثير الوقائي الممكن لمستخلص بذور العنب على أضرار الاكسدة الناجمة عن أشعة غاما، وقد تعرضت الفئران إلى جر عات مجز أة من أشعة غاما (8 جر اى كل بضعة ايام )، وتم اعطاء جر عة يومية من مستخلص بذور العنب مقدار ها100 وزن الجسم ملغم / كغم من وزن الجسم قبل وخلال التعرض للإشتعاع.

وتم التضحية بحيوانات التجارب في اليوم الاول و الر ابع عشر بعد التعرض لأخر جرعة من الأشعاع الجامي.

أظهرت النتائج أن اعطاء مستخلص بذور العنب للفئران المشعة أدي الي التقليل بشكل كبير من التغيرات الناجمة في المنظومة المضادة للأكسدة. وانخفض بشكل ملحوظ تركيز(حمض الثيوبربتيورك) مقارنة مع التركيز في الفئران المعرضة للإشعاع.

الاستثناج : في ضوء النتائج التي تم الحصول عليها من هذه الدراسة من الو اضح أن تناول مستخلص بذور العنب للفئر ان المعرضة للإشعاع يمكن أن يوفر حماية كبيرة ضد أضر ار الأكسدة بسبب قدرة مكوناته علي الحد من الثقائق الحرة والخصائص المضادة للاكسدة. ويمكن أن أثير إلى أن مستخلص بذور العنب يمكن أن يكون له فوائد محتملة بالنسبة إلى الأشخاص الذين يتلقون العلاج الإشعاعي.

الكلمات الدالة : مستخلص بذور العنب,أشعة جاما,الاجهاد التأكسدي,الميتوكوندريا,أنزيمات مضادة للأكسدة 